\title{
Cellular Metabolic Regulation in the Differentiation and Function of Regulatory T Cells
}

\author{
Ye Chen ${ }^{1}{ }^{\circledR}$, Jacob Colello ${ }^{2} \mathbb{D}$, Wael Jarjour ${ }^{1}$ and Song Guo Zheng ${ }^{1, *}$ \\ 1 Division of Rheumatology and Immunology, Department of Internal Medicine at Ohio State University of \\ Medicine and Wexner Medical Center, Columbus, OH 43201, USA; Ye.Chen@osumc.edu (Y.C.); \\ Wael.Jarjour@osumc.edu (W.J.) \\ 2 Division of Rheumatology, Department of Medicine at Penn State College of Medicine, Hershey, PA 17033, \\ USA; jcolello@pennstatehealth.psu.edu \\ * Correspondence: SongGuo.Zheng@osumc.edu; Tel.: +1-614-293-7452
}

Received: 3 January 2019; Accepted: 20 February 2019; Published: 21 February 2019

check for updates

\begin{abstract}
Regulatory T cells (Tregs) are essential for maintaining immune tolerance and preventing autoimmune and inflammatory diseases. The activity and function of Tregs are in large part determined by various intracellular metabolic processes. Recent findings have focused on how intracellular metabolism can shape the development, trafficking, and function of Tregs. In this review, we summarize and discuss current research that reveals how distinct metabolic pathways modulate Tregs differentiation, phenotype stabilization, and function. These advances highlight numerous opportunities to alter Tregs frequency and function in physiopathologic conditions via metabolic manipulation and have important translational implications.
\end{abstract}

Keywords: cell metabolism; T cells; Foxp3; mTOR

\section{Overview of the Effects of Cellular Metabolism on Tregs}

Regulatory T cells (Tregs) are crucial for immune homeostasis and the control of inflammatory disorders [1-4]. We mainly focus the discussion on CD4+CD25+Foxp3+ Tregs in this review. Tregs subsets include: thymus derived Tregs (tTregs), peripheral derived Tregs (pTregs) which are generated extrathymically at peripheral sites, and iTregs that are induced ex vivo following TCR stimulation in the presence of transforming growth factor $\beta$ [5]. Tregs-mediated protection has been applied in numerous preclinical models of autoimmune diseases and transplantation, which informs on their therapeutic potential for human diseases [6-9].

Like conventional CD4+ T cells, Tregs also have a high degree of plasticity related to different transcriptional programs [10-13], which are in turn impacted by cellular metabolism [14]. Recent findings show that Tregs use glycolysis and fatty acid oxidation differently than effector conventional $\mathrm{T}$ cells and naïve $\mathrm{T}$ cells [15]. Compared to effector conventional $\mathrm{T}$ cells, mouse Tregs oxidize lipids at higher rates and exhibit low glycolytic flux in vitro. On the other hand, the modest energy and biosynthesis demands of naïve $T$ cells are typically met by the tricarboxylic acid cycle, lipid oxidation, and glycolysis (Figure 1) [16]. Moreover, glycolysis inhibits Tregs differentiation and promotes Tregs expansion, whereas fatty-acid oxidation (FAO) promotes Tregs differentiation [15,17]. In addition, the expression of Foxp3 in Tregs inhibits Myc expression and reduces glycolysis, which can be suitable for Tregs in low glucose condition [17]. Foxp3, in turn, induces oxidate phosphorylation and increases the ratio of oxidized nicotinamide adenine dinucleotide (NAD) over the reduced form (NADH), allowing Tregs to survive in elevated lactate environments [17]. Furthermore, autophagy is one of the first responses when cells experience nutrient limitation and is critical for Tregs fitness. Deficient autophagy leads to the upregulation of the mechanistic target of rapamycin (mTOR) and c-Myc 
(Myc proto-oncogene) expression as well as an increase in glycolysis, resulting in impaired Tregs function $[18,19]$.



Figure 1. Model of energy usage by naïve $\mathrm{T}$, effector $\mathrm{T}$, and Regulatory $\mathrm{T}$ cells (Tregs). Naïve T cells use glucose, fatty acids, and amino acids as their energy source. Effector T cells have higher energy efficiency and use glucose as their primary energy source. In contrast, the glucose transporter 1 is absent in Tregs and Tregs use fatty-acid oxidation (FAO) as their main energy source.

Different chain lengths of fatty acids have dissimilar effects on Tregs differentiation. Adding a short chain fatty acid to mouse or human naïve CD4+ T cells enhances Tregs differentiation, while a long chain fatty acid (LC-FA) decreases Tregs differentiation [20]. Our previous work demonstrated that sodium butyrate, which belongs to the short-chain fatty acid family, promotes Tregs induction and displays therapeutic potential in several inflammatory disorders [21]. However, Raud et al. recently reported that Carnitine palmitoyltransferase 1a (Cpt1a), a critical regulator of LC-FA oxidation, is largely dispensable for Tregs generation [22].

mTOR is a $289 \mathrm{kDa}$ serine/threonine protein kinase that is highly evolutionarily conserved and has two complexes mTORC1 and mTORC2 [23]. It can directly affect $\mathrm{T}$ cell proliferation and differentiation through the integration of environmental cues such as energy stores, nutrients, and growth factors; and can be selectively inhibited by rapamycin [24]. Generally, mTORC1 is more sensitive to rapamycin than mTORC2 [25], however, in naïve CD4+ T cells, mTORC1 and mTORC2 have essentially the same sensitivity to rapamycin [26]. This review describes the effects of mTOR signaling dependent cellular metabolic regulation on Tregs phenotype and differentiation/suppressive function. Moreover, we discuss the role of mTOR in its modulation of T cell metabolism, which could provide targets for metabolic manipulation.

\section{2. $\mathrm{mTOR}$}

As a member of phosphatidylinositol-3 kinases (PI3K) family, mTOR contains two N-terminal HEAT domains (binding domain), which are important for protein-protein interactions. It also includes an FRB region (rapamycin binding domain of mTOR), a FAT domain (a domain in PI3K-related kinases), a structurally supportive C-terminal FATC domain (a domain in PI3K-related kinases), and a kinase domain [27]. During T cell activation, T cell receptor (TCR) stimulates the mTORC1 and mTORC2 via triggering the recruitment of PI3K to the TCR receptor [28]. The activation of PI3K leads to activation 
of the serine-threonine kinase AKT (also known as protein kinase B) by pyruvate dehydrogenase kinase 1 (PDK1), following the activation of mTOR signaling [29]. Additionally, PI3K can directly induce the activation of mTORC2 [30]. Diverse environmental inputs can be integrated into the mTOR pathway. For example, through mTOR, metabolic cues and immune signals have an ability to direct $\mathrm{T}$ cell fate decisions [31]. Moreover, co-stimulatory signals, TCR and cytokine can activate mTOR via PI3K-AKT signaling to meet energy demands and activate $\mathrm{T}$ cells.

\section{1. mTOR and Tregs Differentiation}

The most profound function of mTOR in Tregs generation was first revealed using the selective inhibitor of mTOR, rapamycin, which decreased the production of effector $\mathrm{T}$ cells and increased the generation of Tregs [32]. Furthermore, a lack of mTORC1 signaling may lead to a failure of differentiation from naïve CD4+ T cells to Th17 lineage. When mTORC2 and mTORC1 were both mutually absent, however, naïve CD4+ T cells were differentiated into Foxp3+ Tregs [33]. This research underscores the significant role of mTOR as a fundamental regulatory factor in the differentiation of Tregs and Th17 cells (Figure 2).

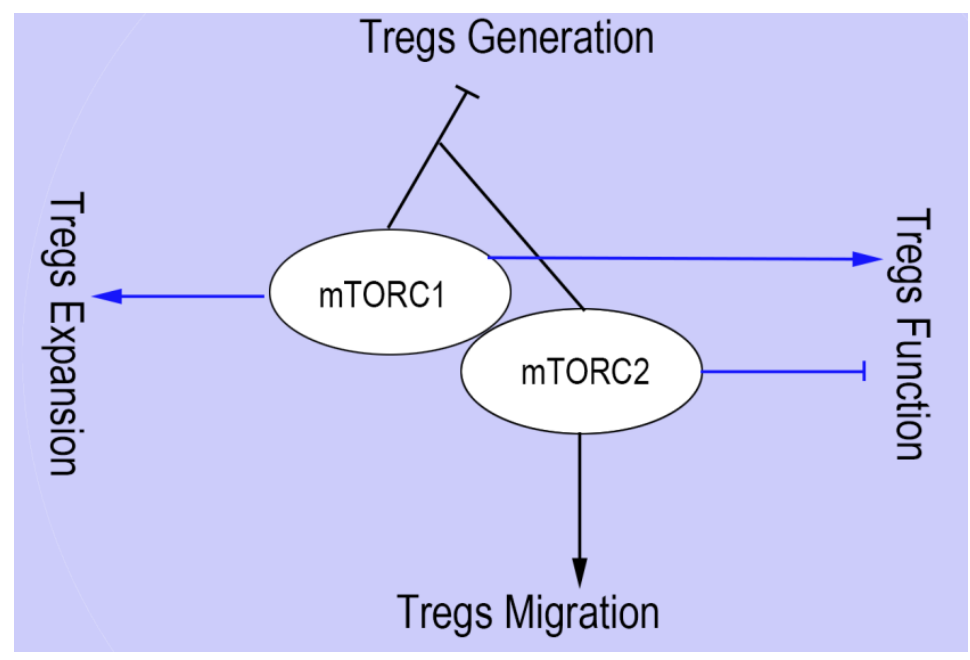

Figure 2. The roles of $\mathrm{mTORC} 1$ and $\mathrm{mTORC} 2$ on Tregs generation, expansion, function, and migration. The absence of mTOR signaling dramatically increase Tregs generation, while deleting either mTORC1 or mTORC2 signaling does not lead to the upregulation of Foxp3+ Tregs. mTORC1 and mTORC2 play opposite roles in Tregs function, the absence of main component Raptor of mTORC1 limits Tregs function, and lack of mTORC2 increases Tregs function via promoting the activity of mTORC1. mTORC2 promotes the migration of Tregs to inflammatory sites. However, the effects of mTORC1 on the Tregs migration remain unclear. mTOR signaling is essential for Tregs expansion. Consequently, Slc3a2-deficient Tregs have an impaired mTORC1 pathway and show lower proliferation ability. However, the role of mTORC2 on Tregs expansion remains unclear.

\section{2. mTOR and Tregs Function}

Tregs generation is enhanced during an immune response by inhibition of mTOR. Such activity is considered a required step in maintaining Tregs suppressive capabilities. Recent evidence has revealed a critical role of mTORC1 complex in the development of Tregs suppressive activity [34] (Figure 2). If Raptor is specifically deleted from Tregs, mTORC1 is disrupted. This leads not only to a profound loss of Tregs suppressive activity, but also causes the development of a fatal early-onset inflammatory disorder. Mechanistically, cholesterol/lipid metabolism is enhanced through Raptor/mTORC1 signaling in Tregs [34]. In order to establish Tregs functional competency, the mevalonate pathway can up-regulate the Tregs suppressive molecules CTLA-4 and ICOS, as well as coordinate Tregs proliferation. Inhibition of the mTORC2 pathway is partly involved in maintaining 
Tregs function by mTORC1 [34]. Nevertheless, mTOR signaling is critical for properly programming activated Tregs function in order to protect tissue homeostasis and preserve immune tolerance. Tregs-specific deletion of mTOR impairs Tregs function and homeostasis, resulting in the spontaneous effector T cell activation and in the development of inflammation in barrier tissues, which is correlated with the reduction in the local tissues of both peripheral Tregs (pTregs) and thymic-derived Tregs (tTregs) [35]. In contrast, Toll-like receptor (TLR) signals enhance Tregs proliferation through mTORC1 signaling pathway, glucose transporter 1 (Glut1) upregulation, and glycolysis. However, these signals decrease the suppressive ability of Tregs [36]. It is likely that the TLR signal results in high levels of pro-inflammatory cytokines such as IL-6, IL-1, TNF $\alpha$, and these pro-inflammatory cytokines decrease Tregs functionality even as Tregs maintain mTORC1 expression.

\section{3. mTOR and Tregs Expansion}

Although rapamycin is commonly used to block tumor cell growth, it is interesting that proliferation of CD4+ $\mathrm{T}$ cell and activation-induced cell death cannot be blocked by rapamycin in vitro and in kidney transplant rejection [37]. On the contrary, expanded Tregs may suppress the proliferation of effector $\mathrm{T}$ cells in vitro as well as prevent allograft rejection in vivo [37,38]. A new study has revealed that branched-chain amino acids (BCAAs) could be essential for the maintenance of Tregs profiling state, through metabolic reprogramming of the amino acid transporter solute carrier family 3 member 1 (Slc3a2) dependent pathway. Slc3a2-deficient Tregs impair the mTORC1 pathway and show lower proliferation ability [39] (Figure 2). The expansion of Tregs by rapamycin usually requires the addition of IL-2. Thus, even when $\mathrm{mTORC1}$ is inhibited by rapamycin [40], IL-2 maintains the ability to expand Treg cells.

\section{4. $m$ TOR and Tregs Migration}

As one of the complexes of mTOR, mTORC2 has been proven to have control of spatial aspects of cell growth via actin reorganization [41,42]. The immune-modulatory function is critically interrelated with the migration of activated Tregs to inflammatory tissue [43]. A recent study demonstrated that glycolysis was beneficial for their relocation. Migration of Tregs to inflamed tissue was initiated by pro-migratory stimuli through a PI3K-mTORC2-mediated signaling pathway, which culminated in stimulation of the enzyme glucokinase (GCK). Subsequently, GCK increases cytoskeletal rearrangements by interacting with actin. If Tregs lack this pathway, they will still be functionally suppressive but will fail to migrate to skin allografts as well as inhibit rejection [44] (Figure 2).

\section{Promising Metabolic Targets to Manipulate Tregs Frequency and Function}

mTOR is a very important regulator of cell survival and plays bidirectional roles in Tregs induction and function. The absence of mTOR signaling dramatically increases Tregs generation and inhibits the function of Tregs. To advance therapeutics and promote homeostasis of the immune system, it is necessary to identify more specific targets that modify Tregs function or induction. Next, we discuss the effects of some mTOR interrelated metabolic regulators on Tregs phenotype.

\subsection{Hypoxia-Inducible Factor $1 \alpha$ (HIF1 $\alpha$ )}

The transcription factor hypoxia-inducible factor (HIF1 $\alpha)$ is a necessary protein for sensing oxygen saturation and subsequently initiating the cellular response to hypoxia [45,46]. It also is closely associated with Tregs and the mTOR pathway. Furthermore, impeding glycolysis up-regulates production of Tregs that occurs through inhibition of mTOR-mediated induction of HIF1 $\alpha$ [45]. Interestingly, HIF1 $\alpha$ inhibits Tregs differentiation in a transcription-independent manner [47], while not affecting Foxp 3 mRNA levels. HIF1 $\alpha$ exerts this inhibition through promoting the degradation of Foxp3 protein by ubiquitination (Figure 3). Moreover, lack of HIF1 $\alpha$ promotes Tregs induction and protects mice from autoimmune neuro-inflammation [45]. 




Figure 3. Metabolic and mTOR signaling control of Regulatory T cells' differentiation. Different ligand binding with aryl hydrocarbon receptor (AHR) leads to dissimilar outcome in Tregs induction. For example, 6-formylindolo [3,2-b] carbazole (FICZ) binding with AHR inhibits Tregs generation while 2,3,7,8-tetrachlorodibenzo- $p$-dioxin (TCDD) promotes Tregs generation. Peroxisome proliferator-activated receptor- $\gamma$ (PPAR- $\gamma$ ) increase Tregs differentiation via regulating the balance between fatty-acid oxidation (FAO) and glycometabolism. AMP-activated protein kinase (AMPK) is an important metabolic checkpoint in Tregs differentiation, and there is controversy regarding the role of the AMPK in Tregs differentiation. mTOR signaling is the most important metabolic regulator of Tregs. If mTOR is absent in naïve CD4+ T cells, it can dramatically increase Tregs differentiation even under normal activating conditions. HIF1 $\alpha$ does not directly regulate the expression of Foxp3. However, it promotes the degradation of Foxp3 protein by ubiquitination.

Inflammation and hypoxia are two independent factors regulating the balance between Th17 and Tregs. Our group reported that tTregs are unstable in the inflammatory environment and fail to suppress collagen-induced arthritis [48]. Mechanistically, the presence of the inflammatory cytokine IL-6 converts tTregs to Th17-like cells in vitro [2,11,12,49], and IL-6 also increases HIF1 $\alpha$ expression in a stat3-dependent manner [47]. Up to this date, it is unclear whether IL-6 regulates Tregs stability via metabolic alteration through HIF1 $\alpha$. A number of published articles reported that HIF $1 \alpha$ is a key regulator in inflammation and autoimmune diseases, such as systemic lupus erythematosus (SLE) [50], rheumatoid arthritis (RA) [51,52], type 1 diabetes (T1DM) [53], multiple sclerosis (MS) [54], psoriasis [55], and inflammatory bowel disease (IBD) [56]. These findings indicate that HIF1 $\alpha$ is a potential target to manipulate Tregs phenotype in autoimmune diseases.

\subsection{AMP-Activated Protein Kinase (AMPK)}

AMPK senses the cellular AMP/ATP ratio and is activated by low energy balance (high AMP/ATP ratio) [57-59]. Activated AMPK promotes FAO via upregulating a series of lipid oxidation related genes, such as Acetyl-CoA carboxylase 1 (ACC1), Acetyl-CoA carboxylase 2 (ACC2), Cpt1a, and sterol regulatory element binding transcription factor 1 (SREVP-1c) [60]. In addition, AMPK also regulates glycolysis via adjusting the expression of Glut1 [61]. AMPK is responsible for Tregs differentiation via regulating the balance of FAO and glycolysis. Activation of AMPK by metformin increases Tregs induction; and in murine models inhibits the progression of experimental autoimmune encephalomyelitis (EAE), and inflammatory bowel disease $[15,62,63]$. TCR activates both AMPK and $\mathrm{mTOR}$, the latter active kinase is a negative regulator for the former one under limited nutrient condition [64]. Interestingly, the absence of AMPK has no effect on Tregs differentiation even though it 
enhances mTORC1 activity. Liver kinase B1 (LKB1) is a best-studied upstream kinase of AMPK and is an important metabolic sensor of Tregs. The absence of LKB1 in Foxp3+ Tregs limits the number and function of Tregs, and the effects of LKB1 on Tregs generation and function are independent of AMPK and mTOR $[65,66]$. Moreover, a recent paper demonstrated that Tregs differentiation was independent of the AMPK-Driven LC-FAO [22].

\subsection{Leptin}

Leptin is a cytokine-like hormone and is structurally similar to IL-6. Leptin mediates metabolism and T cell function $[67,68]$. Chronic leptin- and leptin-receptor deficiency is correlated with resistance to autoimmunity and high susceptibility to infection $[69,70]$. For example, leptin levels in SLE patients are correlated with regulatory $\mathrm{T}$ cell frequency [71]. De Rosa et al. reported that both leptin and its receptor are constitutively expressed in freshly isolated human Tregs. Increased leptin signaling acts as an antagonist during Tregs proliferation (Figure 3) [72].

\subsection{Peroxisome Proliferator-Activated Receptors (PPARs)}

Peroxisome proliferator-activated receptors (PPARs) are nuclear hormone receptors that function to regulate cell growth, homeostasis, and differentiation. PPAR $\alpha, \beta / \delta$, and $\gamma$ are three primary isoforms, each with distinct functions and tissue distribution [73]. PPARs play an important role in peroxisomal mediated $\beta$-oxidation of FAO. When PPARs are activated with specific ligands, conformational changes occur, resulting in heterodimerization with retinoid $X$ receptor $(R X R \alpha)$, which then binds to promoter regions of target genes involved in FAO [74,75]. PPARs also regulate glucose metabolism. Recent studies have demonstrated that agonists of PPARs inhibit inflammatory and immune responses in non-alcoholic fatty liver disease, at least in part, through increased expression of Foxp3 and induction of Tregs (Figure 3) [76,77]. Although studies have revealed a clear picture of anti-inflammatory function by PPAR- $\gamma$, the action of other PPARs on the Tregs population remains uncertain. Recent studies have focused on the relationship between PPARs and visceral adipose tissue (VAT) Tregs. VAT Tregs are a unique subset of Tregs that uniquely express PPAR $\gamma$ and are specifically recruited to adipose tissue to suppress the inflammatory process [78]. In mice that specifically lack PPAR $\gamma$ in Tregs, VAT Treg cell population is reduced. These mice display enhanced insulin resistance and increased susceptibility to diabetic pathology $[79,80]$. These findings suggest that PPAR $\gamma$ may be a promising target for obesity-associated insulin resistance (IR). However, the absence of PPAR $\gamma$ in VAT Tregs does not perturb their frequency in aged mice, and VAT Tregs show a gene expression profile more similar to fat effector conventional T cells than splenic Tregs [81]. One possible reason is that long term inflammation in aged mice may change the characteristics of Tregs and promote the transdifferentiation. These results highlight the importance of PPAR $\gamma$ in Treg differentiation, migration, and function although aging and chronic inflammation may affect the role of PPAR $\gamma$ in Treg biology.

\subsection{The Aryl Hydrocarbon Receptor (AHR)}

AHR exists as a receptor and transcription factor, which is essential for xenobiotic metabolism and shows a cital function in immunity [82]. AHR has a high-affinity ligand, TCDD (2,3,7,8-tetrachlorodibenzo- $p$-dioxin) and when activated in vivo, AHR-TCDD complex leads to the induction of CD4+CD25+Foxp3+ Tregs. Alternatively, 6-formylindolo [3,2-b] carbazole (FICZ) may activate AHR to interfere with Tregs differentiation, boosting Th17 cell differentiation and worsening experimental autoimmune encephalomyelitis (EAE). Therefore, AHR regulates the balance of Tregs and Th17 cell differentiation in a ligand-specific manner (Figure 3) [83] and can be a unique target for immunosuppression therapy.

\subsection{Interleukin $2(I L-2)$}

IL-2 was first found as a T cell growth factor and plays an important role in $\mathrm{T}$ cell proliferation and differentiation [84]. We confirmed, along with several groups, that IL-2 is still necessary to induce and 
expand Tregs [10,85]. Zeng et al. demonstrated that IL-2 enhancement of Tregs function was dependent on the activation of mTORC1 [34]. Interestingly, IL-2 may partner with rapamycin (mTOR inhibitor) in Tregs expansion in vitro (Box 1, Figure 3). Low dose IL-2 is a promising method for the treatment of autoimmune diseases like lupus [86,87], T1DM [88], and graft-versus-host (GVHD) [89,90].

\section{Concluding Remarks and Perspectives}

Recently, research has highlighted the complex roles of intrinsic metabolic pathways in the development and function of Tregs, which may have significant implications on immune diseases and responses. In this review, we briefly summarize the roles of metabolic sensors in the biological features of Tregs as well as their potential to be targets of clinical immune-modifying therapies (Figure 3). Immunometabolism is a promising new field, and profound questions remain to be answered (Box 1).

Box 1. Some unsolved questions in the metabolic regulation of Tregs.

- $\quad$ The different roles of mTORC1 and mTORC2 in Treg induction, migration, expansion, and function;

- The different metabolic profiles of Tregs during steady states and inflammatory conditions;

- Identification of metabolic factors that correlate Tregs development, function, and expansion with environment cues;

- $\quad$ The basis of the requirement of high doses of IL-2 (mTOR activator) along with rapamycin (inhibit mTOR) to expand Tregs in vitro.

Funding: This work was supported by NIH R01 AR059103, NIH Star award and NIH R61 AR073409.

Conflicts of Interest: The authors declare no financial or commercial conflicts of interest.

\section{References}

1. Qian, X.; Wang, K.; Wang, X.; Zheng, S.G.; Lu, L. Generation of human regulatory t cells de novo with suppressive function prevent xenogeneic graft versus host disease. Int. Immunopharmacol. 2011, 11, $630-637$. [CrossRef] [PubMed]

2. Kong, N.; Lan, Q.; Chen, M.; Wang, J.; Shi, W.; Horwitz, D.A.; Quesniaux, V.; Ryffel, B.; Liu, Z.; Brand, D.; et al. Antigen-specific transforming growth factor beta-induced treg cells, but not natural treg cells, ameliorate autoimmune arthritis in mice by shifting the th17/treg cell balance from th17 predominance to treg cell predominance. Arthritis Rheum. 2012, 64, 2548-2558. [CrossRef] [PubMed]

3. Lan, Q.; Zhou, X.; Fan, H.; Chen, M.; Wang, J.; Ryffel, B.; Brand, D.; Ramalingam, R.; Kiela, P.R.; Horwitz, D.A.; et al. Polyclonal cd4+foxp3+ treg cells induce tgfbeta-dependent tolerogenic dendritic cells that suppress the murine lupus-like syndrome. J. Mol. Cell Biol. 2012, 4, 409-419. [CrossRef] [PubMed]

4. Li, B.; Zheng, S.G. How regulatory t cells sense and adapt to inflammation. Cell. Mol. Immunol. 2015, 12, 519-520. [CrossRef] [PubMed]

5. Shevach, E.M.; Thornton, A.M. Ttregs, ptregs, and itregs: Similarities and differences. Immunol. Rev. 2014, 259, 88-102. [CrossRef] [PubMed]

6. Bluestone, J.A.; Bour-Jordan, H. Current and future immunomodulation strategies to restore tolerance in autoimmune diseases. Cold Spring Harb. Perspect. Biol. 2012, 4. [CrossRef] [PubMed]

7. Juvet, S.C.; Whatcott, A.G.; Bushell, A.R.; Wood, K.J. Harnessing regulatory $\mathrm{t}$ cells for clinical use in transplantation: The end of the beginning. Am. J. Transplant. 2014, 14, 750-763. [CrossRef]

8. Horwitz, D.A.; Zheng, S.G.; Gray, J.D.; Wang, J.H.; Ohtsuka, K.; Yamagiwa, S. Regulatory t cells generated ex vivo as an approach for the therapy of autoimmune disease. Semin. Immunol. 2004, 16, 135-143. [CrossRef]

9. Horwitz, D.A.; Gray, J.D.; Zheng, S.G. The potential of human regulatory t cells generated ex vivo as a treatment for lupus and other chronic inflammatory diseases. Arthritis Res. 2002, 4, 241-246. [CrossRef]

10. Zheng, S.G.; Wang, J.; Wang, P.; Gray, J.D.; Horwitz, D.A. Il-2 is essential for tgf-beta to convert naive cd4+cd25- cells to cd25+foxp3+ regulatory t cells and for expansion of these cells. J. Immunol. 2007, 178, 2018-2027. [CrossRef] 
11. Zheng, S.G.; Wang, J.; Horwitz, D.A. Cutting edge: Foxp3+cd4+cd25+ regulatory $\mathrm{t}$ cells induced by il-2 and tgf-beta are resistant to th17 conversion by il-6. J. Immunol. 2008, 180, 7112-7116. [CrossRef] [PubMed]

12. Zhou, X.; Kong, N.; Wang, J.; Fan, H.; Zou, H.; Horwitz, D.; Brand, D.; Liu, Z.; Zheng, S.G. Cutting edge: All-trans retinoic acid sustains the stability and function of natural regulatory $\mathrm{t}$ cells in an inflammatory milieu. J. Immunol. 2010, 185, 2675-2679. [CrossRef] [PubMed]

13. Gu, J.; Lu, L.; Chen, M.; Xu, L.; Lan, Q.; Li, Q.; Liu, Z.; Chen, G.; Wang, P.; Wang, X.; et al. Tgf-beta-induced $\mathrm{cd} 4+\mathrm{foxp} 3+\mathrm{t}$ cells attenuate acute graft-versus-host disease by suppressing expansion and killing of effector cd8+ cells. J. Immunol. 2014, 193, 3388-3397. [CrossRef] [PubMed]

14. Procaccini, C.; Carbone, F.; Di Silvestre, D.; Brambilla, F.; De Rosa, V.; Galgani, M.; Faicchia, D.; Marone, G.; Tramontano, D.; Corona, M.; et al. The proteomic landscape of human ex vivo regulatory and conventional $\mathrm{t}$ cells reveals specific metabolic requirements. Immunity 2016, 44, 406-421. [CrossRef] [PubMed]

15. Michalek, R.D.; Gerriets, V.A.; Jacobs, S.R.; Macintyre, A.N.; MacIver, N.J.; Mason, E.F.; Sullivan, S.A.; Nichols, A.G.; Rathmell, J.C. Cutting edge: Distinct glycolytic and lipid oxidative metabolic programs are essential for effector and regulatory cd4+ $t$ cell subsets. J. Immunol. 2011, 186, 3299-3303. [CrossRef] [PubMed]

16. Pearce, E.L. Metabolism in t cell activation and differentiation. Curr. Opin. Immunol. 2010, 22, 314-320. [CrossRef]

17. Angelin, A.; Gil-de-Gomez, L.; Dahiya, S.; Jiao, J.; Guo, L.; Levine, M.H.; Wang, Z.; Quinn, W.J., 3rd; Kopinski, P.K.; Wang, L.; et al. Foxp3 reprograms t cell metabolism to function in low-glucose, high-lactate environments. Cell Metab. 2017, 25, 1282-1293.e7. [CrossRef]

18. Kabat, A.M.; Harrison, O.J.; Riffelmacher, T.; Moghaddam, A.E.; Pearson, C.F.; Laing, A.; Abeler-Dorner, L.; Forman, S.P.; Grencis, R.K.; Sattentau, Q.; et al. The autophagy gene atg1611 differentially regulates treg and th2 cells to control intestinal inflammation. Elife 2016, 5, e12444. [CrossRef]

19. Wei, J.; Long, L.; Yang, K.; Guy, C.; Shrestha, S.; Chen, Z.; Wu, C.; Vogel, P.; Neale, G.; Green, D.R.; et al. Autophagy enforces functional integrity of regulatory $t$ cells by coupling environmental cues and metabolic homeostasis. Nat. Immunol. 2016, 17, 277-285. [CrossRef]

20. Haghikia, A.; Jorg, S.; Duscha, A.; Berg, J.; Manzel, A.; Waschbisch, A.; Hammer, A.; Lee, D.H.; May, C.; Wilck, N.; et al. Dietary fatty acids directly impact central nervous system autoimmunity via the small intestine. Immunity 2015, 43, 817-829. [CrossRef]

21. Chen, X.; Su, W.; Wan, T.; Yu, J.; Zhu, W.; Tang, F.; Liu, G.; Olsen, N.; Liang, D.; Zheng, S.G. Sodium butyrate regulates th17/treg cell balance to ameliorate uveitis via the nrf2/ho-1 pathway. Biochem. Pharmacol. 2017, 142, 111-119. [CrossRef] [PubMed]

22. Raud, B.; Roy, D.G.; Divakaruni, A.S.; Tarasenko, T.N.; Franke, R.; Ma, E.H.; Samborska, B.; Hsieh, W.Y.; Wong, A.H.; Stuve, P.; et al. Etomoxir actions on regulatory and memory $\mathrm{t}$ cells are independent of cpt1a-mediated fatty acid oxidation. Cell Metab. 2018, 28, 504-515.e7. [CrossRef] [PubMed]

23. Yang, Q.; Guan, K.L. Expanding mtor signaling. Cell Res. 2007, 17, 666-681. [CrossRef] [PubMed]

24. Blouet, C.; Ono, H.; Schwartz, G.J. Mediobasal hypothalamic p70 s6 kinase 1 modulates the control of energy homeostasis. Cell Metab. 2008, 8, 459-467. [CrossRef]

25. Verbist, K.C.; Guy, C.S.; Milasta, S.; Liedmann, S.; Kaminski, M.M.; Wang, R.; Green, D.R. Metabolic maintenance of cell asymmetry following division in activated t lymphocytes. Nature 2016, 532, 389-393. [CrossRef] [PubMed]

26. Delgoffe, G.M.; Pollizzi, K.N.; Waickman, A.T.; Heikamp, E.; Meyers, D.J.; Horton, M.R.; Xiao, B.; Worley, P.F.; Powell, J.D. The kinase mtor regulates the differentiation of helper $t$ cells through the selective activation of signaling by mtorc1 and mtorc2. Nat. Immunol. 2011, 12, 295-303. [CrossRef]

27. Weichhart, T.; Hengstschlager, M.; Linke, M. Regulation of innate immune cell function by mtor. Nat. Rev. Immunol. 2015, 15, 599-614. [CrossRef] [PubMed]

28. Laplante, M.; Sabatini, D.M. Mtor signaling in growth control and disease. Cell 2012, 149, 274-293. [CrossRef]

29. Saxton, R.A.; Sabatini, D.M. Mtor signaling in growth, metabolism, and disease. Cell 2017, 168, 960-976. [CrossRef]

30. Shimobayashi, M.; Hall, M.N. Making new contacts: The mtor network in metabolism and signalling crosstalk. Nat. Rev. Mol. Cell Biol. 2014, 15, 155-162. [CrossRef]

31. Chi, H. Regulation and function of mtor signalling in t cell fate decisions. Nat. Rev. Immunol. 2012, 12, 325-338. [CrossRef] 
32. Zheng, Y.; Collins, S.L.; Lutz, M.A.; Allen, A.N.; Kole, T.P.; Zarek, P.E.; Powell, J.D. A role for mammalian target of rapamycin in regulating t cell activation versus anergy. J. Immunol. 2007, 178, 2163-2170. [CrossRef]

33. Powell, J.D.; Pollizzi, K.N.; Heikamp, E.B.; Horton, M.R. Regulation of immune responses by mtor. Annu. Rev. Immunol. 2012, 30, 39-68. [CrossRef] [PubMed]

34. Zeng, H.; Yang, K.; Cloer, C.; Neale, G.; Vogel, P.; Chi, H. Mtorc1 couples immune signals and metabolic programming to establish $\mathrm{t}(\mathrm{reg})$-cell function. Nature 2013, 499, 485-490. [CrossRef]

35. Chapman, N.M.; Zeng, H.; Nguyen, T.M.; Wang, Y.; Vogel, P.; Dhungana, Y.; Liu, X.; Neale, G.; Locasale, J.W.; Chi, H. Mtor coordinates transcriptional programs and mitochondrial metabolism of activated treg subsets to protect tissue homeostasis. Nat. Commun. 2018, 9, 2095. [CrossRef]

36. Gerriets, V.A.; Kishton, R.J.; Johnson, M.O.; Cohen, S.; Siska, P.J.; Nichols, A.G.; Warmoes, M.O.; de Cubas, A.A.; MacIver, N.J.; Locasale, J.W.; et al. Foxp3 and toll-like receptor signaling balance treg cell anabolic metabolism for suppression. Nat. Immunol. 2016, 17, 1459-1466. [CrossRef] [PubMed]

37. Battaglia, M.; Stabilini, A.; Roncarolo, M.G. Rapamycin selectively expands cd4+cd25+foxp3+ regulatory $\mathrm{t}$ cells. Blood 2005, 105, 4743-4748. [CrossRef]

38. Wang, G.Y.; Zhang, Q.; Yang, Y.; Chen, W.J.; Liu, W.; Jiang, N.; Chen, G.H. Rapamycin combined with allogenic immature dendritic cells selectively expands $c d 4+c d 25+$ foxp $3+$ regulatory $t$ cells in rats. Hepatobiliary Pancreat. Dis. Int. 2012, 11, 203-208. [CrossRef]

39. Ikeda, K.; Kinoshita, M.; Kayama, H.; Nagamori, S.; Kongpracha, P.; Umemoto, E.; Okumura, R.; Kurakawa, T.; Murakami, M.; Mikami, N.; et al. Slc3a2 mediates branched-chain amino-acid-dependent maintenance of regulatory t cells. Cell Rep. 2017, 21, 1824-1838. [CrossRef]

40. Asanuma, S.; Tanaka, J.; Sugita, J.; Kosugi, M.; Shiratori, S.; Wakasa, K.; Shono, Y.; Shigematsu, A.; Kondo, T.; Kobayashi, T.; et al. Expansion of cd4(+)cd25 (+) regulatory t cells from cord blood cd4(+) cells using the common gamma-chain cytokines (il-2 and il-15) and rapamycin. Ann. Hematol. 2011, 90, 617-624. [CrossRef]

41. Cybulski, N.; Hall, M.N. Tor complex 2: A signaling pathway of its own. Trends Biochem. Sci. 2009, 34, 620-627. [CrossRef] [PubMed]

42. Oh, W.J.; Jacinto, E. Mtor complex 2 signaling and functions. Cell Cycle 2011, 10, 2305-2316. [CrossRef] [PubMed]

43. Gao, Y.; Tang, J.; Chen, W.; Li, Q.; Nie, J.; Lin, F.; Wu, Q.; Chen, Z.; Gao, Z.; Fan, H.; et al. Inflammation negatively regulates foxp3 and regulatory t-cell function via dbc1. Proc. Natl. Acad. Sci. USA 2015, 112, E3246-E3254. [CrossRef] [PubMed]

44. Kishore, M.; Cheung, K.C.P.; Fu, H.; Bonacina, F.; Wang, G.; Coe, D.; Ward, E.J.; Colamatteo, A.; Jangani, M.; Baragetti, A.; et al. Regulatory t cell migration is dependent on glucokinase-mediated glycolysis. Immunity 2017, 47, 875-889.e10. [CrossRef] [PubMed]

45. Shi, L.Z.; Wang, R.; Huang, G.; Vogel, P.; Neale, G.; Green, D.R.; Chi, H. Hif1alpha-dependent glycolytic pathway orchestrates a metabolic checkpoint for the differentiation of th17 and treg cells. J. Exp. Med. 2011, 208, 1367-1376. [CrossRef] [PubMed]

46. Guan, S.Y.; Leng, R.X.; Tao, J.H.; Li, X.P.; Ye, D.Q.; Olsen, N.; Zheng, S.G.; Pan, H.F. Hypoxia-inducible factor-1alpha: A promising therapeutic target for autoimmune diseases. Expert Opin. Ther. Targets 2017, 21, 715-723. [CrossRef] [PubMed]

47. Dang, E.V.; Barbi, J.; Yang, H.Y.; Jinasena, D.; Yu, H.; Zheng, Y.; Bordman, Z.; Fu, J.; Kim, Y.; Yen, H.R.; et al. Control of $\mathrm{t}(\mathrm{h}) 17 / \mathrm{t}(\mathrm{reg})$ balance by hypoxia-inducible factor 1. Cell 2011, 146, 772-784. [CrossRef]

48. Kong, N.; Lan, Q.; Chen, M.; Zheng, T.; Su, W.; Wang, J.; Yang, Z.; Park, R.; Dagliyan, G.; Conti, P.S.; et al. Induced $\mathrm{t}$ regulatory cells suppress osteoclastogenesis and bone erosion in collagen-induced arthritis better than natural t regulatory cells. Ann. Rheum. Dis. 2012, 71, 1567-1572. [CrossRef]

49. Xu, L.; Kitani, A.; Fuss, I.; Strober, W. Cutting edge: Regulatory $t$ cells induce cd4+cd25-foxp3- $t$ cells or are self-induced to become th17 cells in the absence of exogenous tgf-beta. J. Immunol. 2007, 178, 6725-6729. [CrossRef]

50. Deng, W.; Ren, Y.; Feng, X.; Yao, G.; Chen, W.; Sun, Y.; Wang, H.; Gao, X.; Sun, L. Hypoxia inducible factor-1 alpha promotes mesangial cell proliferation in lupus nephritis. Am. J. Nephrol. 2014, 40, 507-515. [CrossRef]

51. Hu, F.; Shi, L.; Mu, R.; Zhu, J.; Li, Y.; Ma, X.; Li, C.; Jia, R.; Yang, D.; Li, Y.; et al. Hypoxia-inducible factor-1alpha and interleukin 33 form a regulatory circuit to perpetuate the inflammation in rheumatoid arthritis. PLoS ONE 2013, 8, e72650. 
52. Giatromanolaki, A.; Sivridis, E.; Maltezos, E.; Athanassou, N.; Papazoglou, D.; Gatter, K.C.; Harris, A.L.; Koukourakis, M.I. Upregulated hypoxia inducible factor-1alpha and -2alpha pathway in rheumatoid arthritis and osteoarthritis. Arthritis Res. Ther. 2003, 5, 193-201. [CrossRef] [PubMed]

53. Loukovaara, S.; Koivunen, P.; Ingles, M.; Escobar, J.; Vento, M.; Andersson, S. Elevated protein carbonyl and hif-1alpha levels in eyes with proliferative diabetic retinopathy. Acta Ophthalmol. 2014, 92, 323-327. [CrossRef] [PubMed]

54. Graumann, U.; Reynolds, R.; Steck, A.J.; Schaeren-Wiemers, N. Molecular changes in normal appearing white matter in multiple sclerosis are characteristic of neuroprotective mechanisms against hypoxic insult. Brain Pathol. 2003, 13, 554-573. [CrossRef] [PubMed]

55. Vasilopoulos, Y.; Sourli, F.; Zafiriou, E.; Klimi, E.; Ioannou, M.; Mamuris, Z.; Simos, G.; Koukoulis, G.; Roussaki-Schulze, A. High serum levels of hif-1alpha in psoriatic patients correlate with an over-expression of il-6. Cytokine 2013, 62, 38-39. [CrossRef]

56. Mimouna, S.; Goncalves, D.; Barnich, N.; Darfeuille-Michaud, A.; Hofman, P.; Vouret-Craviari, V. Crohn disease-associated escherichia coli promote gastrointestinal inflammatory disorders by activation of hif-dependent responses. Gut Microbes 2011, 2, 335-346. [CrossRef] [PubMed]

57. Bai, A.; Ma, A.G.; Yong, M.; Weiss, C.R.; Ma, Y.; Guan, Q.; Bernstein, C.N.; Peng, Z. Ampk agonist downregulates innate and adaptive immune responses in tnbs-induced murine acute and relapsing colitis. Biochem. Pharmacol. 2010, 80, 1708-1717. [CrossRef]

58. Gualdoni, G.A.; Mayer, K.A.; Goschl, L.; Boucheron, N.; Ellmeier, W.; Zlabinger, G.J. The amp analog aicar modulates the treg/th17 axis through enhancement of fatty acid oxidation. FASEB J. 2016, 30, 3800-3809. [CrossRef]

59. Park, M.J.; Lee, S.Y.; Moon, S.J.; Son, H.J.; Lee, S.H.; Kim, E.K.; Byun, J.K.; Shin, D.Y.; Park, S.H.; Yang, C.W.; et al. Metformin attenuates graft-versus-host disease via restricting mammalian target of rapamycin/signal transducer and activator of transcription 3 and promoting adenosine monophosphate-activated protein kinase-autophagy for the balance between thelper 17 and tregs. Transl. Res. 2016, 173, 115-130.

60. Tamas, P.; Hawley, S.A.; Clarke, R.G.; Mustard, K.J.; Green, K.; Hardie, D.G.; Cantrell, D.A. Regulation of the energy sensor amp-activated protein kinase by antigen receptor and ca2+ in tlymphocytes. J. Exp. Med. 2006, 203, 1665-1670. [CrossRef]

61. Barnes, K.; Ingram, J.C.; Porras, O.H.; Barros, L.F.; Hudson, E.R.; Fryer, L.G.; Foufelle, F.; Carling, D.; Hardie, D.G.; Baldwin, S.A. Activation of glut1 by metabolic and osmotic stress: Potential involvement of amp-activated protein kinase (ampk). J. Cell Sci. 2002, 115, 2433-2442. [PubMed]

62. Sun, Y.; Tian, T.; Gao, J.; Liu, X.; Hou, H.; Cao, R.; Li, B.; Quan, M.; Guo, L. Metformin ameliorates the development of experimental autoimmune encephalomyelitis by regulating thelper 17 and regulatory $\mathrm{t}$ cells in mice. J. Neuroimmunol. 2016, 292, 58-67. [CrossRef] [PubMed]

63. Lee, S.Y.; Lee, S.H.; Yang, E.J.; Kim, E.K.; Kim, J.K.; Shin, D.Y.; Cho, M.L. Metformin ameliorates inflammatory bowel disease by suppression of the stat 3 signaling pathway and regulation of the between th $17 /$ treg balance. PLoS ONE 2015, 10, e0135858. [CrossRef] [PubMed]

64. Waickman, A.T.; Powell, J.D. Mtor, metabolism, and the regulation of t-cell differentiation and function. Immunol. Rev. 2012, 249, 43-58. [CrossRef] [PubMed]

65. Yang, K.; Blanco, D.B.; Neale, G.; Vogel, P.; Avila, J.; Clish, C.B.; Wu, C.; Shrestha, S.; Rankin, S.; Long, L.; et al. Homeostatic control of metabolic and functional fitness of treg cells by lkb1 signalling. Nature 2017, 548, 602-606. [CrossRef] [PubMed]

66. He, N.; Fan, W.; Henriquez, B.; Yu, R.T.; Atkins, A.R.; Liddle, C.; Zheng, Y.; Downes, M.; Evans, R.M. Metabolic control of regulatory t cell (treg) survival and function by lkb1. Proc. Natl. Acad. Sci. USA 2017, 114, 12542-12547. [CrossRef]

67. Farooqi, I.S.; Matarese, G.; Lord, G.M.; Keogh, J.M.; Lawrence, E.; Agwu, C.; Sanna, V.; Jebb, S.A.; Perna, F.; Fontana, S.; et al. Beneficial effects of leptin on obesity, $t$ cell hyporesponsiveness, and neuroendocrine/metabolic dysfunction of human congenital leptin deficiency. J. Clin. Investig. 2002, 110, 1093-1103. [CrossRef]

68. Matarese, G.; Procaccini, C.; De Rosa, V.; Horvath, T.L.; La Cava, A. Regulatory t cells in obesity: The leptin connection. Trends Mol. Med. 2010, 16, 247-256. [CrossRef] 
69. De Rosa, V.; Procaccini, C.; La Cava, A.; Chieffi, P.; Nicoletti, G.F.; Fontana, S.; Zappacosta, S.; Matarese, G. Leptin neutralization interferes with pathogenic $t$ cell autoreactivity in autoimmune encephalomyelitis. J. Clin. Investig. 2006, 116, 447-455. [CrossRef]

70. Matarese, G.; Di Giacomo, A.; Sanna, V.; Lord, G.M.; Howard, J.K.; Di Tuoro, A.; Bloom, S.R.; Lechler, R.I.; Zappacosta, S.; Fontana, S. Requirement for leptin in the induction and progression of autoimmune encephalomyelitis. J. Immunol. 2001, 166, 5909-5916. [CrossRef]

71. Wang, X.; Qiao, Y.; Yang, L.; Song, S.; Han, Y.; Tian, Y.; Ding, M.; Jin, H.; Shao, F.; Liu, A. Leptin levels in patients with systemic lupus erythematosus inversely correlate with regulatory t cell frequency. Lupus 2017, 26, 1401-1406. [CrossRef] [PubMed]

72. De Rosa, V.; Procaccini, C.; Cali, G.; Pirozzi, G.; Fontana, S.; Zappacosta, S.; La Cava, A.; Matarese, G. A key role of leptin in the control of regulatory t cell proliferation. Immunity 2007, 26, 241-255. [CrossRef] [PubMed]

73. Dreyer, C.; Krey, G.; Keller, H.; Givel, F.; Helftenbein, G.; Wahli, W. Control of the peroxisomal beta-oxidation pathway by a novel family of nuclear hormone receptors. Cell 1992, 68, 879-887. [CrossRef]

74. Kliewer, S.A.; Umesono, K.; Noonan, D.J.; Heyman, R.A.; Evans, R.M. Convergence of 9-cis retinoic acid and peroxisome proliferator signalling pathways through heterodimer formation of their receptors. Nature 1992, 358, 771-774. [CrossRef] [PubMed]

75. Choi, J.M.; Bothwell, A.L. The nuclear receptor ppars as important regulators of t-cell functions and autoimmune diseases. Mol. Cells 2012, 33, 217-222. [CrossRef] [PubMed]

76. Pawlak, M.; Lefebvre, P.; Staels, B. Molecular mechanism of pparalpha action and its impact on lipid metabolism, inflammation and fibrosis in non-alcoholic fatty liver disease. J. Hepatol. 2015, 62, 720-733. [CrossRef]

77. Zhu, Y.; Ni, Y.; Liu, R.; Hou, M.; Yang, B.; Song, J.; Sun, H.; Xu, Z.; Ji, M. Ppar-gamma agonist alleviates liver and spleen pathology via inducing treg cells during schistosoma japonicum infection. J. Immunol. Res. 2018, 2018, 6398078. [CrossRef]

78. Cipolletta, D.; Feuerer, M.; Li, A.; Kamei, N.; Lee, J.; Shoelson, S.E.; Benoist, C.; Mathis, D. Ppar-gamma is a major driver of the accumulation and phenotype of adipose tissue treg cells. Nature 2012, 486, 549-553. [CrossRef]

79. Hontecillas, R.; Bassaganya-Riera, J. Peroxisome proliferator-activated receptor gamma is required for regulatory cd4+ $\mathrm{t}$ cell-mediated protection against colitis. J. Immunol. 2007, 178, 2940-2949. [CrossRef]

80. Cipolletta, D. Adipose tissue-resident regulatory t cells: Phenotypic specialization, functions and therapeutic potential. Immunology 2014, 142, 517-525. [CrossRef]

81. Bapat, S.P.; Myoung Suh, J.; Fang, S.; Liu, S.; Zhang, Y.; Cheng, A.; Zhou, C.; Liang, Y.; LeBlanc, M.; Liddle, C.; et al. Depletion of fat-resident treg cells prevents age-associated insulin resistance. Nature 2015, 528, 137-141. [CrossRef] [PubMed]

82. Stockinger, B.; Di Meglio, P.; Gialitakis, M.; Duarte, J.H. The aryl hydrocarbon receptor: Multitasking in the immune system. Annu. Rev. Immunol. 2014, 32, 403-432. [CrossRef] [PubMed]

83. Quintana, F.J.; Basso, A.S.; Iglesias, A.H.; Korn, T.; Farez, M.F.; Bettelli, E.; Caccamo, M.; Oukka, M.; Weiner, H.L. Control of $\mathrm{t}(\mathrm{reg})$ and $\mathrm{t}(\mathrm{h}) 17$ cell differentiation by the aryl hydrocarbon receptor. Nature 2008, 453, 65-71. [CrossRef] [PubMed]

84. Smith, K.A. Interleukin-2: Inception, impact, and implications. Science 1988, 240, 1169-1176. [CrossRef] [PubMed]

85. Sakaguchi, S. Naturally arising foxp3-expressing cd25+cd4+ regulatory $\mathrm{t}$ cells in immunological tolerance to self and non-self. Nat. Immunol. 2005, 6, 345-352. [CrossRef] [PubMed]

86. Mizui, M.; Tsokos, G.C. Low-dose il-2 in the treatment of lupus. Curr. Rheumatol. Rep. 2016, 18, 68. [CrossRef] [PubMed]

87. Von Spee-Mayer, C.; Siegert, E.; Abdirama, D.; Rose, A.; Klaus, A.; Alexander, T.; Enghard, P.; Sawitzki, B.; Hiepe, F.; Radbruch, A.; et al. Low-dose interleukin-2 selectively corrects regulatory t cell defects in patients with systemic lupus erythematosus. Ann. Rheum. Dis. 2016, 75, 1407-1415. [CrossRef]

88. Rosenzwajg, M.; Churlaud, G.; Mallone, R.; Six, A.; Derian, N.; Chaara, W.; Lorenzon, R.; Long, S.A.; Buckner, J.H.; Afonso, G.; et al. Low-dose interleukin-2 fosters a dose-dependent regulatory $t$ cell tuned milieu in t1d patients. J. Autoimmun. 2015, 58, 48-58. [CrossRef] 
89. Koreth, J.; Kim, H.T.; Jones, K.T.; Lange, P.B.; Reynolds, C.G.; Chammas, M.J.; Dusenbury, K.; Whangbo, J.; Nikiforow, S.; Alyea, E.P., 3rd; et al. Efficacy, durability, and response predictors of low-dose interleukin-2 therapy for chronic graft-versus-host disease. Blood 2016, 128, 130-137. [CrossRef]

90. Matsuoka, K.; Koreth, J.; Kim, H.T.; Bascug, G.; McDonough, S.; Kawano, Y.; Murase, K.; Cutler, C.; Ho, V.T.; Alyea, E.P.; et al. Low-dose interleukin-2 therapy restores regulatory $t$ cell homeostasis in patients with chronic graft-versus-host disease. Sci. Transl. Med. 2013, 5. [CrossRef]

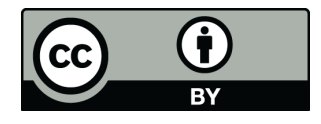

(C) 2019 by the authors. Licensee MDPI, Basel, Switzerland. This article is an open access article distributed under the terms and conditions of the Creative Commons Attribution (CC BY) license (http:/ / creativecommons.org/licenses/by/4.0/). 